\title{
Editorial Comment on the Highlight Article "Revision of the depth record of bony fishes with notes on hadal snailfishes (Liparidae, Scorpaeniformes) and cusk eels (Ophidiidae, Ophidiiformes)" by Mackenzie E. Gerringer et al.
}

\author{
Scott Hamilton ${ }^{1}$ \\ Published online: 22 October 2021 \\ (c) The Author(s), under exclusive licence to Springer-Verlag GmbH Germany, part of Springer Nature 2021
}

Keywords Deep sea $\cdot$ Maximum depth $\cdot$ Physiological limits

How deep can fishes live in the ocean? This intriguing question has perplexed marine biologists for decades. Given the existence of a maximum depth limit for fishes, additional questions revolve around the ecophysiological constraints of extreme pressure for life in the hadal zone and the unique adaptations that allow some species of fish to live near that threshold. In this review article, Gerringer et al. (2021) attempt to settle some of the debate. They review the maximum depth records of bony fishes with a critical eye identifying and correcting confounding information in the literature and the methodological challenges with verifying samples were collected only from the deepest depths. Altogether, the evidence strongly supports the notion that fishes can exist down to at least depths of $8000 \mathrm{~m}$ and potentially a little bit deeper. Deep dwelling fishes often infuse their tissues with the osmolyte trimethylamine-N-oxide (TMAO), which stabilizes proteins under high pressure. TMAO concentrations in fish tissues increase with depth, however at $\sim 8200 \mathrm{~m}$ the cells become isosmotic and cannot further accumulate TMAO (Yancey et al. 2014). Interestingly, the deepest records of two fish species closely approach this theoretical limit, lending credence to the hypothesis that ecophysiological constraints set the depth limit for fishes. The review article discusses the ecological role of hadal fishes, unique physiological adaptations (sensory systems, activity levels, buoyancy) to living at the deepest depths, and how certain groups may have evolved to inhabit these unique niches. Emphasis is placed on dissecting why snailfishes (family Liparidae) and cusk eels (family Ophidiiadae) are so dominant at hadal depths compared to other deep sea fish taxa. The paper concludes by providing suggestions for future research to further disentangle the mechanisms responsible for determining the maximum depth record for fishes in the ocean.

\section{References}

Gerringer ME, Linley TD, Nielsen JG (2021) Revision of the depth record of bony fishes with notes on hadal snailfishes (Liparidae, Scorpaeniformes) and cusk eels (Ophidiidae, Ophidiiformes). Mar Biol. https://doi.org/10.1007/s00227-021-03950-8

Yancey PH, Gerringer ME, Drazen J, Rowden AA, Jamieson AJ (2014) Marine fish may be biochemically constrained from inhabiting the deepest ocean depths. Proc Natl Acad Sci USA 111:4461-4465. https://doi.org/10.1073/pnas.1322003111

Publisher's Note Springer Nature remains neutral with regard to jurisdictional claims in published maps and institutional affiliations.
Scott Hamilton

shamilton@mlml.calstate.edu

1 Moss Landing Marine Laboratories, San Jose State University, Moss Landing, CA, USA 